\title{
A Review of Localization Reform of China's State-owned Enterprises
}

\author{
Yang Zhenyu \\ School of Public Finance and Management \\ Yunnan University of Finance and Economics, Kunming, Yunnan, China \\ youngzhenyu@foxmail.com
}

\begin{abstract}
The reform of State-owned Enterprises(SOEs) is important not only for China's process towards marketization, but also for its long term growth and competition worldwide. This paper provides a systematic review of the reform, which has been made in the past three decades. Then, it focuses on the localization process of SOEs, which is neglected by most of researches. Through localization, the ownership and supervision right of SOEs was transformed from upper level of government to lower levels of local government. Thus, the reform can potentially affect the performance of SOEs. This paper proposes several possible channels through which localization may work, such as more supports from local government, more unwanted interventions or worse market segmentation. Finally, it proposes suggestions which are beneficial for the further development of the reform.
\end{abstract}

Keywords-State-owned Enterprises; Localization; Local Governments;

\section{INTRODUCTION}

The past three-decade witnessed the processes made in China's State-owned Enterprises (SOEs) towards marketization. Because of its importance for the transition in which the "Semi-Market, Semi-Planned" economy is replaced by a market-dominating one, it has attracted attentions of economists since the earlier 1980s, when reform and openness began. Though it is pointed out that the expansion of SOEs in the past years was achieved with substantial social or economic payments, like the accumulation of bad loans in the banking system, the large-scale unemployment, the suppression of private sectors and the inefficient use of resources, a consensus has achieved, that is, the reform of SOEs did enhance the enterprises performance of through varies of mechanisms (Bai, et al. 2006). The hypotheses proposed to comprehend the growth of SOEs concentrate into two streams: some insist the significance of ownership structure and advocate further privatization ( $\mathrm{Hu}$, et al. 2006); others weight more on the perfecting market environment and propose to harden the soft-bounded budgets and alleviate entry restrains in monopolistic industries (Lin, et al. 1995).

Actually, the gradual reform in China's SOEs proceeded through two separate but complementary pathways: privatization and localization. After privatization, small-scale state enterprises were sold to privates while private, institution or foreign investors were introduced into larger ones to diversify ownership structures, mainly by issuing shares. Meanwhile, internal control rights were shifted from officials to managers to enhance governance. After localization, governmental ownership still in hands of varies levels of governments were shifted from the superior authorities to their subordinates with financial burdens and final control rights. Relative to the privatization process on which lots of studies have been done, localization has hardly entered into researchers' perspectives as state ownership of SOEs hold by the central and the local governments are considered approximately homogeneous, thus the shifts would have no impacts on enterprise performance. This judgment may be true before but can no longer be justified after a series of reforms in which the local governments being given tax revenue, financial jurisdiction and other incentives became relatively independent entities with special benefits and concerns. How does localization affect performances of China's state enterprises? It was hard to answer since none continuous and complete data relevant to localization before the middle term of 1990s were available. The purpose of this study is to propose several potential channels through which the reform can affect SOEs, thus make the further process more clear and robust.

\section{POSITIVE EFFECTS OF LOCALIZATION FOR}

\section{PERFORMANCE OF SOES}

Unlike privatization, which partially or completely shifts the ownership and the control rights of state enterprises to privates or institution investors, localization keeps the rights in the hands of the governments over the decentralization processes. After localization, local governments gain higher direct control rights, while being given more operation risks, debt burdens and superfluous workers in these enterprises. The central then still indirectly control the enterprises through its subordinates. Most localization cases were implemented under similar procedures: state enterprises previously supervised by the central or provincial State-owned Assets Supervision and Administration Commission as units of the gigantic company groups were transformed to the lower level commissions, which are subordinates of both the upper level commissions and the local governments.

\section{A. Greater Concerns and Supports from Local Governments}

Though it is admitted that the local governments show much more enthusiasm in supporting and protecting state enterprises under their charge, no detailed discussions have been done. A primary explanation may rest on the fact that localized state enterprises, if being kept well-performing, would bring officials private incomes and political chips. Two theories can be introduced to explain the changes before and after localization.One is the Political Patronage Theory proposed by Shleifer and Vishny (1994), which concerns the determinants for privatization of state enterprises. According to the theory, the incentives faced by officials who hold the ultimate control rights are multidimensional: political gains, like individual reputation, expanded influence, and career 
prospects, and incomes, including allowances, dividends and political rents, both decide officials' preferences. To make the operation decisions matched to their wills, governments are inclined to control enterprises if allowed to do so. Localization provides officials more channels to affect enterprises and to engage in rents-creations. Furthermore, expanded jurisdictions make them able to control. Under the tax allocation arrangements between the central and the locals, revenues directly from localized state enterprises are sometimes crucial for the locals. Only the Political Patronage Theory is not enough to completely explain why local officials themselves, as individuals, also have higher enthusiasm on localized state enterprises. Zhou Li-an (2007) introduces the Promotion Tournament Model to investigate the Chinese political governance structure and its high-powered incentives on local officials. Three characters make China's political system distinguished: the superior officials, rather than the public, hold the authorities to appoint, promote or dismiss their subordinates; placed in the pyramidal bureaucratic system, local officials on similar ranks compete with each other for limited promotion opportunities; promotion probabilities are tightly relevant to the regional economic performances, such as the annual growth rate of GDP or the export revenues.

The Political Patronage Theory and the Promotion Tournament Model together bring us insights to understand the internal mechanisms for local officials' increased concerns and supports to localized state enterprises: localized enterprises are significant and reliable revenue sources for both local governments and individual officials; well-performing enterprises enhance regional economic performances and then officials' career prospects; localized enterprises are also essential mediums through which officials' multidimensional objectives on economic growth and community governance can be implemented. Moreover, local governments own the resources to support and protect their enterprises. Sometimes the supports and protections are essential for state enterprises' survivals and growths, since in China the property rights are still ill-defined and protected, regional entry restrains are widely exist and officials often misuse their jurisdictions to intervene enterprises' operations. Since the early stage of the reforms, administration jurisdictions on public issues, such as processing land use applications, or drafting market administration rules, have been shifted to the locals. Meanwhile, though the banking system was restructured in the middle term of 1990 s to be more independent, local governments still influence loan issues. Furthermore, the reform strategy which puts products markets ahead productive factors markets brings more authorities on public-owned resources to local governments (Naughton 1994). Finally, by issuing "Hukou", people's permanent registrations in a special district, primarily to workers in state enterprises, local governments make state enterprises more attractive to labors. Positions in municipal projects are also provided to workers dismissed in localized state enterprises, which greatly alleviates their resistances when they are fired.

\section{B. More Effective Monitoring}

Since China's underdeveloped markets for products, factors, and managers fail to exactly reflect the real competence of state enterprises and thus the capabilities of managers, outside monitoring mainly from officials are necessary to alleviate insider control problems. Costs of monitoring arise with the extension of management hierarchies as information becomes incomplete and distorted when transmitted. The shorter the distance between basic production units and ultimate supervisors, the less degree for the information is distorted and the fewer incentives are needed for concerned supervisors. As close observers and direct supervisors, local governments access more and better information about enterprises in their districts than the central. Sometimes these direct observations provide valuable details that can never reflected by accounting reports. In China, managers of state enterprises and governmental officials share the same bureaucratic ranking system, which means it's frequent for officials to be appointed as state enterprises' managers and vice versa (Wang Hongling 2000). Localization results in their more rotations and then better acquaintance of local officials with enterprises' daily running.

\section{Enhanced Competent Capabilities and More Business}

\section{Opportunities}

One of the most distinctive features for nearly all transitional economies is the rapid entry and formation of new businesses after the remove of restrains on entries into industries monopolized by state enterprises. Long term central-commanded arrangement distorted prices and resources allocations, led to short supply of products. Moreover, restrictions on mobility of productive factors, like assets and labors, and on transactions of lands hindered local communities from translating resources into income streams (Naughton 1994). As a means for communities to appropriate the benefits of resources while keep their public-ownership unchanged, huge amounts of municipal state enterprises or collective enterprises emerged in suburban areas. In the earlier term, these enterprises were proved to be a flexible and effective adaptation to the changed environment, though many of them were small, inferior-equipped and without appropriate production technologies.

On the one hand, these new emerging municipal enterprises did contribute to regional economic growth and provide additional employment opportunities; on the other hand, they became direct challenges for existent state enterprises: their products were exact substitutes and they asked for production resources. Excess competitions, especially in China's immature market economy, were sometimes disastrous for capital accumulations, technology advances and long term growth.

Localization made it easier and profitable for local governments to restructure district industries. Municipal enterprises in similar industries were integrally merged into localized state enterprises with their workers, assets and debts while unnecessary logistical sectors of state enterprises, such as hospitals, schools or stores, were transferred to local governments and integrated into the public service system. By absorbing new productive capacities and abandoning unproductive burdens, state enterprises enhanced their monopoly powers. Additionally, after being the subordinates of local governments, localized state enterprises are given more business opportunities in public projects sponsored and funded by the locals.

\section{Definite Governmental Backing}

For the central state enterprises, though they do enjoy some supports and privileges, sometimes these patronages are not as high-powered as needed: the central officials' attention is dispersed into numerous enterprises under their charge and the officials face weaker incentives to support as they can't directly gain benefits. Also, central state enterprises are simultaneously under the charges of several ministries, all of 
which own some jurisdictions but no definite responsibilities. Localization means enhanced and definite governmental backing for state enterprises: local governments show more concerns to state enterprises of their own; they are willing to serve as guarantors of loans because of their better assessments of the business prospects and bigger influence on managers' investment decisions; they also serve as intermediaries in cross-district investments and businesses cooperation; finally, they are mouthpieces trying for the central's favorable industrial policies.

\section{NEGATIVE EFFECTS OF LOCALIZATION FOR}

\section{PERFORMANCE OF SOES}

The benefits and the unwanted effects coming with state enterprises' localization are the two sides of the same coin: greater concerns and controls may bring enhanced and sometimes harmful interventions and alleviated autonomies. At least three negative effects can be identified. Still, these negative effects would be eliminated with appropriate measures.

\section{A. More Governmental Interventions}

Even after the restructurings of China' s state enterprises for the so-called Modern Enterprise Institution, the top managers are still directly or indirectly appointed by various levels of governments which are either the only sponsors or the biggest share holders. Thus, the top managers face multiple restrictions: they are both entrepreneurs taking charge of these enterprises under authorizations and virtual officials in the uniform bureaucratic system; their decisions, especially the critical ones, must be sanctioned by superiors before being put into practice; their operations can be manipulated to fulfill goals contrary to profitability, such as employment. Also, the officials' interventions originate from their considerations on private benefits since the performances of state enterprises affect their successions or promotions. In extreme cases, to gain personal reputations and career prospects, officials may force enterprises to engage in unnecessary and uncertain expansions. These interventions can be destructive for enterprises' long term development especially when the money needed is collected through loans or enterprise debts.

\section{B. Market Splits and Entry Barriers}

Montinola, Yingyi Qian and Weingast (1995) propose the "Federalism, Chinese Style" hypothesis to explain China's economic miracle. Decentralization of administration jurisdictions in the earlier term of $1980 \mathrm{~s}$ rendered local governments more autonomy in their districts while reforms in finance and tax system allowed the locals to share revenues with the central. The changes not only induced local governments to maintain the markets for regional economic growth, but also transformed local governments into direct competitors in attracting outside investors, employing resources and seizing market shares. The competitions are further intensified because the industrial structures among neighboring districts are similar to each other. To protect local enterprises and promote economy, the optimal strategy for local officials is to help their enterprises gain advantages at least in the local markets with either entry restrains or discrimination in public-funded projects. Localization may worsen the unfairness faced by state enterprises: officials would prefer to sacrifice efficiency rather than contribute to performance of their competitors. Hence, localization may result in shrinkage of market shares for localized state enterprises with nationwide businesses. In the meantime, localization weakens state enterprises' influences on the central, whose industrial policies and regulations have substantial impacts.

\section{Aggravated Insiders Control and Outsiders Control}

Simplification in management hierarchy does not always lead to alleviation in information asymmetry and agent problem. In contrast, it may enhance the probabilities that managers of localized state enterprises collude with officials to gain private benefits by encroaching public property rights. Similar to privatization, localization weakens the central's control on state enterprises, then leaves managers and local officials added autonomy, which also means added room to manipulate enterprises. Compared with the ministries, local governments lose professional knowledge and experience to monitor managers and to assess enterprises' performances. Managers may intentionally exaggerate difficulties and deficits or underestimate risks to gain bargaining advantages (Sicular 1994).

\section{CONCLUSION}

It is possible to employ localization as an effective means to invigorate state enterprises while prohibit its negative effects, if reforms in the other regimes can be propelled in time, such as the perfecting of markets, the restructuring of internal governance and the relevant political renovations. That's the condition in most of mature market economies and democratic societies. Through the detailed analysis above, several primary judgement about the impacts of localization on state enterprises can be proposed. Generally speaking, localization is expected to impact positively on state enterprises since relatively definite property right arrangement is proved to enhance economic efficiency. The net effects of localization on the performance of a given state enterprise should be heavily influenced by approximate three exogenous factors, which are market environment, internal governance and political arrangement respectively. Marketization hardens the budget constrains for both localized state enterprises and local governments; Internal governance restructurings introduce new mechanisms to monitor top managers' behaviors, thus alleviate the insider control problem; while appropriate political arrangement restrains the outsider control problem. Hence, the correlations between localization and final performance vary under different combinations of these three factors.

\section{REFERENCE:}

[1] Andrei Shleifer and Robert W. Vishny (1994), Politicians and Firms, Quarterly Journal of Economics, 104, 995-1025.

[2] Barry Naughton (1994), Chinese Institutional Innovation and Privatization from Below, American Economic Review, 84, 266-270.

[3] Bai Chong-en; Jiangyong Lu; and Zhigang Tao (2006), The Multitask Theory of State Enterprise Reform: Empirical Evidence from China, American Economic Review, 96, 353-357.

[4] Bai Chong-en; Lu Jiangyong; and Tao Zhigang (2006), An Empirical Study on the Effects of Ownership Reform in China, Economic Research Journal, 8, 4-13. (in Chinese)

[5] Dewenter, K. L. and P. H. Malatesta (2001), State-owned and Private-owned Firms: An Empirical Analysis of Profitability, Leverage, and Labor Intensity, American Economic Review, 91, 320-334.

[6] Ownership Structure Reform on the Performance of China's Enterprises Social Science in China, 4, 50-64. (in Chinese) 
[7] Lin; Cai Fang; and Li Zhou (1995), The Core of SOEs Reform is Creating Competitive Climate, Reform, 2, 17-28. (in Chinese)

[8] Liu Xiaoxuan (1995), The Ownership Structures of State and Non-state Enterprises and the Corresponding Impacts on Performance, Economic Research Journal, 7, 11-20. (in Chinese)

[9] Liu Xiaoxuan (2003), The Structure of Property Rights in the Chinese Transition Economy, Economic Research Journal, 1, 21-29. (in Chinese)

[10] Qian Sun; Wolson H. S.Tong; and Jing Tong (2002), How Does Government Ownership Affect Firm Performance? Evidence from China's Privatization Experience, Journal of Business Finance \& Accounting, 29(1) \& (2), 1-27.

[11] Song Ligang and Yao Yang (2005), Impacts of Restructuring on Firm Performance in China, Social Science in China, 2, 17-31. (in Chinese)

[12] Terry Sicular (1995), Why Are Chinese Sate Enterprises Trapped Into Loss, Economic Research Journal, 4, 21-28. (in Chinese)
[13] Wang Hongling (2000), Agents' Governmental Backing and Its Impacts on Enterprise Performance, Economic Research Journal, 7, 56-62. (in Chinese)

[14] Wei Li (1994), The Impact of Economic Reform on the Performance of Chinese State Enterprises, 1980-1989, The Journal of Political Economy, 105, 1080-1106.

[15] Xia Lijun and Chen Xinyuan (2007), Marketization, SOE Reform Strategy, and Endogenously Determined Corporate Governance Structure, Economic Research Journal, 7, 82-95. (in Chinese)

[16] Yu Lai (2002), The Problem of Control by Outsiders of National Industries, Management World, 2, 95-102. (in Chinese)

[17] Zhou Li-an (2007), Governing China's Local Officials: An Analysis of Promotion Tournament Model, Economic Research Journal, 7, 36-50. (in Chinese) 